\begin{tabular}{llll} 
The Journal of Nepalese Business Studies & Vol. I & No. 1 & Dec. 2004 \\
\hline
\end{tabular}

\title{
Human Resource Management: Career Development
}

\author{
Dhruba Kumar Budhathoki*
}

\begin{abstract}
This paper mainly emphasizes on career development which is gaining much importance in recent times in order to retain skilled, competent and result oriented people in the organization. This paper invites special attention in this area of organizations.
\end{abstract}

PEOPLE ARE THE SOURCES of all productive effort in organizations. Organizational effectiveness depends on the performance of people working in organizations. Better people achieve better results. As a part of human resource management, every organization should acquire and retain skilled, competent, and motivated employees, because the full potential of human resources needs to be achieved for the growth of the organization. For the purpose of retaining skilled employees, management should assist individuals to plan their careers with realistic information about career opportunities that exist within a particular organization. Career planning is a recently developed phenomenon and organizations are nowadays looking $\mathrm{HRD}$ in this new angle.

The tremendous growth of organizations in recent times due to technological improvements and tough competition in global market necessitates the organizations not only to select the right type of staffs, but also to retain them in the organizations. The dynamic and growth oriented employees should be allowed to grow through career development programs because the high turnover of such potential staff leads to great loss in terms of cost, quality and productivity. Dougles T. Hall Says career as

The individually perceived sequence of attitudes and behavior associated with the work related experiences and activities over the span of the person's life.' Thus, a career refers to both attitude and behavior and it is work related. Each person's career is unique. It has an upward mobility i.e. making more money, having more responsibility, acquiring more status and power.

\section{Career Performance}

Handsome monetary as well as fringe benefits and elevation in job are the main indicators of career performance. The modern organizations are basically interested in career performance since it has a direct relationship with goal attainment. The two aspects -the extent of organization's performance appraisal, and the pessimistic attitude of the individual to realize the career effectiveness-should be well understood by the management for better career development. So, career performance is the integrated effort of both management and the employees.

\section{Motivation and Career Development}

Motivation is defined as 'all those of inner striving conditions described as needs, drives, desires, motives and so forth. It is the inner state that activates or moves.' An individual is motivated if he puts forth his best efforts, always working at performing the job and directing his efforts towards accomplishment of goals.

Managers are concerned about employees accomplishing significant work goals-output, quality and cost consciousness. Assisting the employees in career development ensures the organization to attain these goals. In this connection, it is essential to mention about Abraham Maslow's need hierarchy theory of motivation. Maslow says the need of highest level-self actualization need is achieved by a person only after satisfying the lower order

* Mr. Budhathoki isTeaching Assistant, Faculty of Management, PNC, Pokhara. 


\section{The Journal of Nepalese Business Studies}

needs such as physiological, safety, social and esteem needs. It is necessary on the part of the managers to satisfy all the basic needs of an employee and also the self-actualization need. Self actualization like self-fulfillment, personal growth, assignment of challenging job, creativity, risk taking, maximum skill potential etc, are possible through better career development programs.

\section{Career Planning and Pathing}

Career planning involves matching an individual's career aspirations with the opportunities available in an organization. Career pathing is a sequential pattern of the specific jobs associated with those opportunities. The two processes are intertwined. Career planning involves identifying the means of accomplishing desired results, and in this regard of career plans, career paths are the means of achieving aspirations. Although, career planning is still a new practice, most of the organizations are turning to it as a way to protect rather than react to the problems associated with the career.

The individual most identify his career aspirations and abilities and then recognize what training and development are required to follow a particular career path, whereas the organization must identify the needs and opportunities.

\section{Career Development Programs}

The organizations have to develop right type of career development programs so as to make the people grow to their full potential and to retain skilled, competent and talented employees in the organization. Some organizations use career development programs to identify the pool of talent available for promotion and posting, some organizations often restrict career development programs to managerial and professional staff, while some other provide it for both managerial and non-managerial staffs.

The relationship between career development and human resource planning is obvious. Career developments ensure a supply of abilities and talents, whereas human resource planning projects demand for talents and abilities. The supportive and integrated effort of top-level management of the organization as well as system analyst for effective career development and human resource planning are needed for maximizations of both demand and supply of talents and abilities.

Organization structure also often causes failure in the integration of efforts of career development. The failure on the part of the personnel department to coordinate other departments of the organization to place right people in the right jobs through proper planning often causes as a barrier for the people to develop their careers.

\section{Conclusions}

In Nepal, the increasing demand for right people in organization is tremendous due to changing economic scenario. Nowadays, the organizations are becoming international in their operations. To withstand the international competition, organization should develop and retain skilled, talented and motivated employees so as to develop quality, cost consciousness and productivity but it is no doubt that human resource planning and career development are the two vital pillars on which the organizations stand strongly.

\section{REFERENCES}

Agrawal, Govinda Ram. 2057. Dynamics of Human Resource Management in Nepal. Kathmandu: Buddha Academy.

American Accounting Association.1973. Report of the Committee on HRA. The Accounting Review 48: 200-230.

Decenzo, D.A. and S.P. Robbins.1988. Human Resource Management. New Delhi: Prentice - Hall of India Pvt. Ltd.

William, B.W. and Keith Davis. 1993. Human Resource and Personnel Management. New York: MC Grow - Hill. 